\title{
Influence of self-motivation and intrinsic motivational factors for small and medium business growth: A South African case study
}

\begin{tabular}{|c|c|}
\hline \multicolumn{2}{|c|}{$\begin{array}{l}\text { Authors: } \\
\text { Thandukwazi R. Ncube }{ }^{1} \\
\text { Robert W.D. Zondo } 10\end{array}$} \\
\hline \multicolumn{2}{|c|}{$\begin{array}{l}\text { Affiliations: } \\
{ }^{1} \text { Department of } \\
\text { Entrepreneurial Studies and } \\
\text { Management, Faculty of } \\
\text { Management Sciences, } \\
\text { Durban University of } \\
\text { Technology, South Africa }\end{array}$} \\
\hline \multicolumn{2}{|c|}{$\begin{array}{l}\text { Corresponding author: } \\
\text { Robert Zondo, } \\
\text { dumisaniz@dut.ac.za }\end{array}$} \\
\hline \multicolumn{2}{|c|}{$\begin{array}{l}\text { Dates: } \\
\text { Received: } 23 \text { June } 2017 \\
\text { Accepted: } 01 \text { Mar. } 2018 \\
\text { Published: } 29 \text { May } 2018\end{array}$} \\
\hline \multicolumn{2}{|c|}{$\begin{array}{l}\text { How to cite this article: } \\
\text { Ncube, T.R. \& Zondo, R.W.D., } \\
2018 \text {, 'Influence of self- } \\
\text { motivation and intrinsic } \\
\text { motivational factors for small } \\
\text { and medium business growth: } \\
\text { A South African case study', } \\
\text { South African Journal of } \\
\text { Economic and Management } \\
\text { Sciences 21(1), a1994. } \\
\text { https://doi.org/10.4102/ } \\
\text { sajems.v21i1.1994 }\end{array}$} \\
\hline \multicolumn{2}{|c|}{$\begin{array}{l}\text { Copyright: } \\
\text { (C) 2018. The Authors. } \\
\text { Licensee: AOSIS. This } \\
\text { is licensed under the } \\
\text { Creative Commons } \\
\text { Attribution License. }\end{array}$} \\
\hline \multicolumn{2}{|l|}{ Read online: } \\
\hline 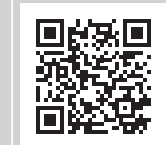 & $\begin{array}{l}\text { Scan this QR } \\
\text { code with your } \\
\text { smart phone or } \\
\text { mobile device } \\
\text { to read online. }\end{array}$ \\
\hline
\end{tabular}

Background: This study investigates the influence of intrinsic motivational factors for small and medium enterprise (SME) growth in the eThekwini District Municipality in South Africa (SA).

Aim: It examines whether self-motivation of business owners operating in the furniture manufacturing sector has an influence on SME growth.

Setting: Of the 127 SMEs operating in the eThekwini District Municipality, 112 participated in the study representing $88 \%$ of the target population.

Methods: Descriptive, chi-square and correlative analyses were used to test the two objectives. That is, to determine the influence of self-motivation of business owners for SME growth, as well as to establish the intrinsic motivational factors that stimulate creativity for SME growth.

Results: The study revealed that the intrinsic motivational factors of business owners do influence SME growth in SA. These factors include exerting effort for business growth interest, finding new solutions to business problems to achieve growth, growing business for recognition, belief to produce the desired outcomes, taking responsibilities for business expansion, the need for advancement, and growth aspiration that enables the business owner to take risks in order to grow the business.

Conclusion: The outcome is that a self-motivated business owner has the ability to grow the business. The study provides valuable data relating to intrinsic motivational factors. Such factors are the enablers of creativity and business growth. It provides initial baseline data upon which to base future work.

\section{Introduction}

When exploring the failure of businesses in both the private and public sector to absorb the growing number of job seekers in SA, increased attention is focused on entrepreneurship and its potential in contributing to economic growth as well as job creation (Ramukumba 2014). Despite the contributions of new small and medium enterprises (SMEs), their failure rate in SA is among the highest in the world. About 75\% of new SMEs do not become established formal businesses (Snyman, Schutte \& Leipzig 2014). According to Olawale and Garwe (2010), the probability of a new SME surviving in the early stages of its existence, is less than any other Global Entrepreneurship Monitored (GEM) sampled country, as listed in the 2015/2016 Global Report. Grouping by geographic region and economic development level, these include Botswana and Morocco (in Africa), India, China and Australia (in Asia and Oceania), Argentina (in Latin America and Caribbean), Bulgaria and Belgium (in Europe), as well as Canada (in North America). While the GEM reports, among others, presents the entrepreneurial behaviour and attitudes of individual business owners, it raises a question as to whether running a small business leads to the fulfillment of personal goals. Arguably, this may depend, on one hand, whether there is a link between small business owners' goals and motivations or, on the other hand, the business outcomes. Hence, this study examines whether small business growth is a function of the small business owner's personal ability to grow the business. It investigates the intrinsic motivational factors that influence SME growth in SA. According to Nieman and Nieuwenhuizen (2014), growth and the desire to grow should be embedded in the mindset of the person starting or creating a new business venture. Growth will intensify the demands made on the resources, which can only be countered by an ability to attract resources. Growth and performance are generally seen as substitutes for each other. A growing business is usually considered to be a successful business that performs well (Nieman \& Nieuwenhuizen 2014). However, this study considers the following 
objectives: to determine the influence of self-motivation of business owners for SME growth and to establish whether the intrinsic motivational factors of business owners influence SME growth. SME owners are likely to be intrinsically motivated if they attribute their business growth to factors under their own control, believe that they have the skills to be effective agents in reaching their desired goals, and are interested in growing a business, not just in achieving wealth (Grant \& Berry 2011). Wiklund, Patzelt and Shepherd (2009) add that self-motivation is the need for self-fulfillment.

\section{Theoretical considerations}

This section presents an overview of motivation, its influence on SME growth, the intrinsic motivation in SMEs as well as motivation and creativity in SMEs.

\section{Overview of motivation}

Motivation is a process that accounts for an individual's intensity, direction and persistence of effort towards attaining a goal (Robbins, Odendaal \& Roodt 2011). Intensity is concerned with how hard a person tries. However, high intensity is unlikely to lead to job performance outcomes unless the effort is channeled in a direction. Robbins et al. (2011) add that the persistency dimension measures how long a person can maintain their effort. Motivated individuals stay with a task long enough to achieve their goal. Hence, the needs theory of McClelland and Koestner (1992) contends that individuals are motivated by three basic drives: achievement, affiliation and power. Tu and Lu (2014) argue that these needs not only motivate individuals but also include many of the most important human goals and concerns. This research attempts to demonstrate that each of these need dimensions affects the level of accountability a person feels for himself or herself and others. However, this section will only focus on the achievement and power needs as they are relevant to SME growth (Pinder 2014).

\section{Achievement needs}

The need for achievement describes a person's drive to excel with respect to some established set of standards (Bande et al. 2016). It refers to the motive to do well and achieve a goal relative to a set of standards. The inclusion of measures of achievement orientation within the framework of entrepreneurs' personal characteristics is consistent with this research. The need to achieve reflects individuals' orientation, the willingness and drive for satisfaction or a sense of accomplishment (Pinder 2014). This is demonstrated by the exertion of intense, prolonged and repeated efforts to accomplish something difficult, whether by skill, practice or perseverance. This is accomplished by a future-oriented dedication to the task involving prioritisation of accomplishing the task and frequently sacrificing other activities and personal time (Royle \& Hall 2012). Individuals' achievement needs are satisfied when they are able to actualise their own purposes relative to and regardless of the situations of others (Pinder 2014). Individuals with high achievement needs do not like to prosper by chance but rather seek personally identifiable sources for their success and cannot leave the outcome to probability (Royle \& Fox 2011). Such individuals experience joy or sadness contingent upon the identifiable outcomes of their efforts (McClelland \& Koestner 1992).

\section{Power needs}

The need for power denotes individuals' desire to be influential. This could manifest itself in attempts to make others behave as one would like or in a manner that they might not have done otherwise (McClelland \& Koestner 1992). In other words, the individuals that are high in this need seek position power so that they can compel the actions of others. Those high in power needs prefer being in competitive, status-driven situations, and actively seek the trappings of status (Royle \& Hall 2012). They are concerned with ensuring that the methods they choose to influence others are within their control (Csikszentmihalyi \& Wong 2014). However, in order to maintain viable interdependent relationships with others, individuals with high power needs must often restrain these desires (Royle \& Hall 2012). Central to one's need for power is gaining influence over others. Individuals with influence can then parlay informal accountability for others into the accumulation of additional resources that serve to enhance their status. Consequently, this study examines business owners' influential behaviour that is related to SME growth.

\section{Motivation and its influence on small and medium enterprises growth}

In work settings, productivity can be increased by using extrinsic rewards such as bonuses, but the actual quality of the work performed is influenced by intrinsic factors (Pinder 2014). If one is doing something that one finds rewarding, interesting and challenging, one is more likely to come up with novel ideas and creative solutions (Csikszentmihalyi \& Wong 2014). Management's motivation, creativity and skills have an influence on the way a business is managed or mismanaged. Insufficient and inappropriate skills of management could cause failure in businesses (Arasti, Zandi \& Talebi 2012). Motivation, in this case, refers to a process that elicits control and sustains certain behaviours (Zimmerman \& Chu 2013). It can either be extrinsic or intrinsic in nature. Extrinsic motivation has a stronger relationship with material factors, while the individual in the intrinsic position attempts to fulfill his or her aims in life (Becchetti, Castriota \& Tortia 2013). This study determines whether intrinsic motivation influence SME growth. It must be noted that human motivation plays a critical role in the entrepreneurial process (Antonites \& Van Vuuren 2014). Grant and Berry (2011) have stressed the importance of entrepreneurial intentions as a forerunner to establishing a new venture, thus highlighting the importance of what motivates a person to grow a business. Consequently, Tu and $\mathrm{Lu}$ (2014) provide clarity in that motivation plays an important part in the creation of new businesses. They indicate that theories of business creation that fail to address this notion are incomplete. 
Motivation can also be defined as a driving force that causes the flux from desire to will in life (Zimmerman \& Chu 2013). For example, a plant with no water still desires water to sustain life. However, due to its incapability to move and get water, the plant cannot get water, thus suffering from a break in the driving force of motivation. It is not to say, however, that the plant necessarily lacks driving force. Therefore, all life can be said to have, at its very minimum, the igniting spark of motivation. Hence, it can be considered a psychological state that compels or reinforces an action towards a desired goal (Tu $\&$ Lu 2014). For example, hunger is a motivation that elicits a desire to eat. Thus, motivation is an action directed towards something specific, and this something is a need to be intrinsically motivated (Grant \& Berry 2011). Therefore, the need is an internal motive (i.e. intrinsic) for acting, leading to the set of actions (e.g. to grow the business). Motivation can also be described as behaviour towards the achievement of a goal. It is an action directed towards something specific, and this something is a need to be intrinsically motivated. Thus, the need is the motive (the reason) for acting. Consequently, this study determines whether SME owners are driven by intrinsic motivational factors in growing their businesses.

\section{Intrinsic motivation in small and medium enterprises}

Intrinsic motivation occurs when one acts without any obvious external rewards (Zimmerman \& Chu 2013). It refers to the reason why one performs certain activities for inherent satisfaction or pleasure (Hennessey 2010). It arises from the individual's positive reaction to the task itself such as interest, involvement, curiosity, satisfaction, or positive challenge, which serves as a type of reward for the work (Grant \& Berry 2011). From the Self Determination Theory, intrinsic motivation is central to the proactive, growth-oriented nature of human beings, which is the basis for learning and development (Deci \& Ryan 2011).

Grant and Berry (2011) confirm that intrinsically motivated business owners are more likely to pursue enjoyment, interest, satisfaction of curiosity, self-expression, or personal challenge in business. Intrinsic motivation is a natural motivational tendency and a critical element in cognitive, social, and physical development (Hennessey 2010). According to Bande et al. (2016), SME owners who are intrinsically motivated, are more likely to engage in the business willingly and work towards improving their skills. Grant and Berry (2011) state that SME owners are likely to be intrinsically motivated if they attribute their business growth to factors under their own control (also known as autonomy), believe that they have the skills to be effective agents in reaching their desired goals (also known as self-efficacy), and are interested in growing a business, not just in achieving wealth.

\section{Motivation and creativity in small and medium enterprises}

Creativity is one of the most important factors in developing and growing businesses (Csikszentmihalyi \& Wong 2014). The emphasis of this study is to examine the conditions under which intrinsic motivation promotes creativity. Coon and Mitter (2010) believe that intrinsic motivation is an important enabler of creativity. According to Hennessey (2010), intrinsic motivation is the desire of interest and the enjoyment of work that is being performed. Coon and Mitter (2010) identify the three interrelated psychological mechanisms through which intrinsic motivation may stimulate creativity.

Firstly, the emotional theorists proposed that when business owners are intrinsically motivated, they experience positive effect (Becchetti et al. 2013). This stimulates creativity by broadening the range of cognitive information available, expanding the scope of attention towards assimilating a wider set of ideas and encouraging cognitive flexibility for identifying patterns and associations between ideas (Grant \& Berry 2011).

Secondly, Deci and Ryan (2011) propose that when business owners are intrinsically motivated, their curiosity and interest in learning enhances their cognitive flexibility, willingness to take risks, and openness to complexity, which, in turn, expands their access to ideas and potential solutions.

Thirdly, both the emotion and self-determination theorists suggest that intrinsic motivation promotes creativity by encouraging persistence. By fostering a positive effect, intrinsic motivation enhances psychological engagement and builds energy for sustaining effort, increasing the amount of time that SME owners are willing and able to work on their tasks (Coon \& Mitterer 2010). This relates to the emotional theories of motivation. On the other hand, by fostering confidence and interest, the intrinsic motivation encourages SME owners to persist with challenging tasks, as well as to concentrate their attention more effectively on these tasks (Hennessey 2010). This relates to self-determination theories of motivation. However, this study is designed around the following questions:

- Does self-motivation of business owners influence SME growth?

- Do intrinsic motivational factors of business owners influence SME growth?

\section{Methodology}

The study methodology will be discussed under the following headings: the target population, profiles of respondents and sample size, data collection method, as well as the measurement and analysis.

\section{Target population}

This study had a target population of 127 SME owners of furniture manufacturing businesses operating in the eThekwini District Municipality. Furniture manufacturers is one of the most labour-intensive industries in South Africa (Department of Trade and Industry 2014). They were selected to participate in this study based on their potential of 
TABLE 1: Total turnover and gross assets of furniture manufacturing industry.

\begin{tabular}{lll}
\hline Size class & Total turnover & $\begin{array}{l}\text { Total gross asset value } \\
\text { (fixed property excluded) }\end{array}$ \\
\hline Medium & R51 million & R19 million \\
Small & R13 million & R5 million \\
Very small & R5 million & R2 million \\
Micro & R0.20 million & R0.10 million \\
\hline
\end{tabular}

Source: Mahembe, E., 2011, Literature review on small and medium enterprises' access to credit and support in South Africa, Underhill Corporate Solutions, National Credit Regulato (NCR), Pretoria, South Africa

contributing to the reduction of unemployment, increased exports and the development of SMEs.

\section{Brief profiles of respondents and sample size}

Of the 127 SMEs, 112 participated in the study. The majority of SMEs at $60 \%$ have been operating for more than 5 years. Seventy-eight per cent of the participants were male and twenty-two per cent were female business owners. The following Table 1 provides the total turnover and gross asset value of furniture manufacturing industry in relation with their size classes.

\section{Data collection method}

A list of the furniture manufacturers was obtained from the Durban Chamber of Businesses. Recruitment of respondents was undertaken with the aim of ensuring that all the 127 furniture manufacturing SMEs would participate in the study. The questionnaires were forwarded through electronic mail to the owners of SMEs who represented their businesses. However, 78 completed questionnaires were returned via electronic mail and the remaining 34 were physically collected from their businesses, representing an $88 \%$ response rate, considered high compared with the norm for survey responses (Baruch \& Holtom 2008). The main reason for this high response rate was due to the invitation letter sent to all the SME furniture manufacturing owners and consistently follow-up of questionnaires through telephone calls.

\section{Measurement and analysis}

In line with the research framework, the study measured 13 variables using the questionnaire. It employed a Likert scale ranging from 1 (strongly agree) to 5 (strongly disagree).

\section{Self-motivation of business owners for small and medium enterprise growth}

Six items listed in this variable (as informed by Antonites \& Van Vuuren 2014; Csikszentmihalyi \& Wong 2014; Tu \& Lu 2014; Zimmerman \& Chu 2013) are:

- self-motivated SME owners are likely to grow their businesses even bigger,

- when business owners are self-motivated they experience positive effect,

- being self-motivated is the reason behind SME growth,

- SME growth is regarded as an important goal of the business,

- interest in learning enhances SME owners' willingness to take risks, and

- SME growth increases a business's sustainability.
A reliability analysis Cronbach's alpha of 0.676 was achieved. This value is close to 0.7 and indicates an internal consistency and reliability of the variables in this objective.

\section{Intrinsic motivational factors of business owners for small and medium enterprise growth}

The variables in this objective were measured by seven items and based on the intrinsic motivational factors of business owners for SME growth (Grant \& Berry 2011; Pinder 2014). These include:

- as a self-motivated business owner I exert effort based on business growth interest,

- I find new solutions to business problems because I want to achieve business growth,

- I grow my business because I want to be recognised,

- I am driven by belief to produce the desired outcomes of my business,

- the aim of expanding the business is to take responsibility,

- my need for advancement is the personal attribute that has great impact on the growth of my business, and

- my growth aspiration enables me to take risk in order to grow my business.

A reliability analysis Cronbach's alpha of 0.626 was achieved. This value is also close to 0.7 and indicates an internal consistency and reliability of the variables in this objective.

Descriptive statistics, chi-square and correlation tests were used to analyse data. In addition, SPSS (version 23.0) was used for data analysis.

\section{Study results}

\section{Self-motivation of business owners for} small and medium enterprise growth

This section presents findings on the influence of selfmotivation of business owners for SME growth.

\section{Descriptive analysis}

The result in Table 2 shows that the SME owners are selfmotivated to grow their businesses. Percentage agreement ranges from $93.3 \%$ to $96.7 \%$. Eighty per cent of the owners indicated that their interest in learning enhances willingness

TABLE 2: Self-motivation of business owners for small and medium enterprise growth.

\begin{tabular}{ll}
$\begin{array}{l}\text { Variables for self-motivation for SME } \\
\text { growth }\end{array}$ & $\begin{array}{l}\text { Percentage response accepting the } \\
\text { self-motivation of business owners } \\
\text { for SME growth variable }\end{array}$ \\
\hline $\begin{array}{l}\text { Self-motivated SME owners are likely to } \\
\text { grow their businesses even bigger. }\end{array}$ & 96.7 \\
$\begin{array}{l}\text { When business owners are self- } \\
\text { motivated, they experience positive } \\
\text { effect. }\end{array}$ & 95.0 \\
$\begin{array}{l}\text { Being self-motivated is the reason behind } \\
\text { SME growth. }\end{array}$ & 93.3 \\
$\begin{array}{l}\text { SME growth is regarded as an important } \\
\text { goal of the business. }\end{array}$ & 93.3 \\
$\begin{array}{l}\text { Interest in learning enhances SME } \\
\text { owners' willingness to take risks. }\end{array}$ & 80.0 \\
$\begin{array}{l}\text { SME growth increases the business } \\
\text { sustainability. }\end{array}$ & 95.0 \\
\hline
\end{tabular}

SME, small and medium enterprise. 
TABLE 3: Chi-square statistics for self-motivation of business owners for small and medium enterprise growth.

\begin{tabular}{llllll}
\hline $\begin{array}{l}\text { Statistical technique } \\
\text { used }\end{array}$ & $\begin{array}{l}\text { Self-motivated SME } \\
\text { owners are likely to } \\
\text { grow their businesses } \\
\text { even bigger }\end{array}$ & $\begin{array}{l}\text { When business owners } \\
\text { are self-motivated, } \\
\text { they experience } \\
\text { positive effect }\end{array}$ & $\begin{array}{l}\text { Being naturally } \\
\text { motivated is the } \\
\text { reason behind SME } \\
\text { growth }\end{array}$ & $\begin{array}{l}\text { SME growth is } \\
\text { regarded as an } \\
\text { important goal of the } \\
\text { business }\end{array}$ & $\begin{array}{l}\text { Interest in learning } \\
\text { enhances SME owners' } \\
\text { willingness to take } \\
\text { risks }\end{array}$ \\
\hline Chi-square & $108.300^{\mathrm{a}}$ & $102.700^{\mathrm{a}}$ & $97.300^{\mathrm{a}}$ & $\begin{array}{l}\text { SME growth increases } \\
\text { the business } \\
\text { sustainability }\end{array}$ \\
$d f$ & 2 & 2 & 2 & $45.067^{\mathrm{b}}$ & $5.700^{\mathrm{a}}$ \\
Asymptotic significance & 0.000 & 0.000 & 0.000 & 1 & 2 \\
\hline
\end{tabular}

a 0 cells $(0.0 \%)$ have expected frequencies less than 5 . The minimum expected cell frequency is 20.0 .

b, 0 cells $(0.0 \%)$ have expected frequencies less than 5 . The minimum expected cell frequency is 30.0 .

$\mathrm{SME}$, small and medium enterprise.

TABLE 4: Correlation tests for self-motivation of business owners for small and medium enterprise growth.

\begin{tabular}{|c|c|c|}
\hline Variable & $\begin{array}{l}\text { Statistical technique } \\
\text { used }\end{array}$ & $\begin{array}{l}\text { Self-motivated SME owners } \\
\text { are likely to grow their } \\
\text { businesses even bigger }\end{array}$ \\
\hline \multirow{2}{*}{$\begin{array}{l}\text { When business owners are } \\
\text { self-motivated, they } \\
\text { experience positive effect }\end{array}$} & Correlation & 0.681 \\
\hline & Significance (two-tailed) & 0.000 \\
\hline \multirow{2}{*}{$\begin{array}{l}\text { Being naturally motivated } \\
\text { is the reason behind SME } \\
\text { growth }\end{array}$} & Correlation & 0.505 \\
\hline & Significance (two-tailed) & 0.000 \\
\hline \multirow{2}{*}{$\begin{array}{l}\text { SME growth is regarded } \\
\text { as an important goal of the } \\
\text { business }\end{array}$} & Correlation & 0.503 \\
\hline & Significance (two-tailed) & 0.000 \\
\hline \multirow{2}{*}{$\begin{array}{l}\text { Interest in learning } \\
\text { enhances SME owners' } \\
\text { willingness to take risks }\end{array}$} & Correlation & 0.062 \\
\hline & Significance (two-tailed) & 0.638 \\
\hline \multirow{2}{*}{$\begin{array}{l}\text { SME growth increases the } \\
\text { business sustainability }\end{array}$} & Correlation & 0.285 \\
\hline & Significance (two-tailed) & 0.027 \\
\hline
\end{tabular}

Note: Correlation is significant at the 0.05 level (two-tailed).

SME, small and medium enterprise.

TABLE 5: Intrinsic motivational factors for small and medium enterprise growth.

Variables for intinsic

motivational factors

Percentage response accepting the intrinsic motivational factor variable

As a self-motivated business owner, I exert effort 93.3

based on business growth interest.

I find new solutions to business problems because I 95.0

want to achieve business growth.

I grow my business because I want to be recognised. $\quad 58.3$

I am driven by a belief to produce the desired $\quad 96.7$

outcomes of my business.

The aim of expanding the business is to take 88.3

responsibility.

My need for advancement is the personal

attribute that has great impact on the growth of

my business.

My growth aspiration enables me to take risk in

order to grow my business.

to take risks and 95\% indicated that SME growth increases business sustainability. These high agreement percentage responses affirm that self-motivation is a veritable tool in the growth and development of SMEs. This is confirmed by GayPerret and Mainali (2012) who state that self-motivation is much better than simple motivation that involves financial incentive. It also concurs with the views of Shepherd and Wiklund (2009) who agree that motivation behind venture creation is the need for self-fulfillment.

The chi-square test for each variable was also performed. Hence, Table 3 presents test results for determining whether the scoring patterns across the different statements were similar.

The $p$-values of all the variables in Table 3 are less than the 0.05 level of significance. This implies the significant relationship of the variables on self-motivation of business owners for SME growth.

\section{Correlation test}

The bivariate Pearson correlation analyses were used to examine the strength of the identified association between variables (Dawson 2009). These tests were used to find any significant relationship between study variables. They include the relationship of both the self-motivation and intrinsic motivational factors of business owners with SME growth. The bivariate Pearson's correlation can reveal the significance of the correlation and, if it is significant, whether it is positive or negative (i.e. the direction of the correlation) as well as the strength of the correlation.

The relationship in Table 4 for determining whether selfmotivated SME owners are likely to grow their businesses even bigger was analysed:

- The self-motivation of a SME owner variable has a directly proportional correlation with the four variables relating to business growth. These variables include the positive effect of self-motivated business owners, the naturally motivated business owner as the reason for SME growth, SME growth as an important goal of the business, as well as the SME growth as a variable that increases business sustainability. They have coefficient $r$-values of $0.681 ; 0.505 ; 0.503$ and 0.285 , respectively (at $p>0.05$ ). This analysis indicates that self-motivated SME owners have the potential to grow their businesses.

- The variable relating to self-motivated SME owners who are likely to grow their businesses does not have a significant relationship with the variable on SME owners' interest in learning to enhance willingness to take risks (at $p<0.05$ ). This analysis indicates that an interest in learning by self-motivated SME owners has no relation to business growth.

\section{Intrinsic motivational factors of business owners for small and medium enterprise growth}

This section presents findings on the influence of intrinsic motivational factors of business owners for SME growth.

\section{Descriptive analysis}

Table 5 presents results (in percentages) of intrinsic motivational factors for SME growth.

The result in Table 5 indicates that the intrinsic motivational factors of business owners have an influence on SME growth. The high percentage agreement values on intrinsic motivation factors range from $88.3 \%$ to $98.3 \%$. The response with low percentage agreement at $58.3 \%$ is when business owners 
TABLE 6: Chi-square statistics of intrinsic motivational factors for small and medium enterprise growth.

\begin{tabular}{|c|c|c|c|c|c|c|c|}
\hline $\begin{array}{l}\text { Statistical } \\
\text { technique used }\end{array}$ & $\begin{array}{l}\text { As a self-motivated } \\
\text { business owner, I } \\
\text { exert effort based } \\
\text { on business growth } \\
\text { interest }\end{array}$ & $\begin{array}{l}\text { I find new solutions } \\
\text { to business } \\
\text { problems because I } \\
\text { want to achieve } \\
\text { business growth }\end{array}$ & $\begin{array}{l}\text { I grow my } \\
\text { business because } \\
\text { I want to be } \\
\text { recognised }\end{array}$ & $\begin{array}{l}\text { I am driven by a } \\
\text { belief to produce } \\
\text { the desired } \\
\text { outcomes of my } \\
\text { business }\end{array}$ & $\begin{array}{l}\text { The aim of } \\
\text { expanding the } \\
\text { business is to take } \\
\text { responsibility }\end{array}$ & $\begin{array}{l}\text { My need for } \\
\text { advancement is the } \\
\text { personal attribute } \\
\text { that has great impact } \\
\text { on the growth of my } \\
\text { business }\end{array}$ & $\begin{array}{l}\text { My growth } \\
\text { aspiration enables } \\
\text { me to take risk in } \\
\text { order to grow my } \\
\text { business }\end{array}$ \\
\hline Chi-square & $45.067^{a}$ & $102.700^{b}$ & $18.900^{b}$ & $52.267^{\mathrm{a}}$ & $35.267^{a}$ & $56.067^{a}$ & $60.400^{b}$ \\
\hline$d f$ & 1 & 2 & 2 & 1 & 1 & 1 & 2 \\
\hline $\begin{array}{l}\text { Asymptotic } \\
\text { significance }\end{array}$ & 0.000 & 0.000 & 0.000 & 0.000 & 0.000 & 0.000 & 0.000 \\
\hline
\end{tabular}

a 0 cells $(0.0 \%)$ have expected frequencies less than 5 . The minimum expected cell frequency is 30.0 .

b, 0 cells $(0.0 \%)$ have expected frequencies less than 5 . The minimum expected cell frequency is 20.0 .

TABLE 7: Correlation tests of intrinsic motivational factors for business growth.

\begin{tabular}{|c|c|c|}
\hline Variable & Statistical technique used & $\begin{array}{l}\text { As a self-motivated } \\
\text { business owner, I exert } \\
\text { effort based on business } \\
\text { growth interest }\end{array}$ \\
\hline \multirow{2}{*}{$\begin{array}{l}\text { 'I find new solutions to } \\
\text { business problems because } \\
\text { I want to achieve business } \\
\text { growth.' }\end{array}$} & Correlation & 0.467 \\
\hline & Significance (two-tailed) & 0.000 \\
\hline \multirow{2}{*}{$\begin{array}{l}\text { 'I grow my business } \\
\text { because I want to be } \\
\text { recognised.' }\end{array}$} & Correlation & -0.067 \\
\hline & Significance (two-tailed) & 0.610 \\
\hline \multirow{2}{*}{$\begin{array}{l}\text { 'I'm driven by a belief to } \\
\text { produce the desired } \\
\text { outcomes of my business.' }\end{array}$} & Correlation & 0.338 \\
\hline & Significance (two-tailed) & 0.008 \\
\hline \multirow{2}{*}{$\begin{array}{l}\text { 'The aim of expanding the } \\
\text { business is to take } \\
\text { responsibility.' }\end{array}$} & Correlation & 0.210 \\
\hline & Significance (two-tailed) & 0.107 \\
\hline \multirow{2}{*}{$\begin{array}{l}\text { 'My need for advancement } \\
\text { is the personal attribute } \\
\text { that has great impact on } \\
\text { the growth of my business.' }\end{array}$} & Correlation & 0.319 \\
\hline & Significance (two-tailed) & 0.013 \\
\hline \multirow{2}{*}{$\begin{array}{l}\text { 'My growth aspiration } \\
\text { enables me to take risk in } \\
\text { order to grow my business.' }\end{array}$} & Correlation & 0.394 \\
\hline & Significance (two-tailed) & 0.002 \\
\hline
\end{tabular}

Note: Correlation is significant at the 0.05 level (two-tailed).

indicate that they want to grow their businesses because they want to be recognised. The majority of respondents confirmed the position held by Gay-Perret and Mainali (2012) who stated that business owners with an internal locus of control should exert effort and persistence towards achieving their goals and grow businesses. Such business owners are able to control outcomes, and their actions do determine the achievement of rewards.

In addition, the chi-square test per each variable was also performed. Table 6 presents test results for determining whether the scoring patterns across the different statements were similar.

The $p$-values for all the variables in Table 6 are less than the 0.05 level of significance. This implies the significant relationship of the variables, thus indicating that the business owners are influenced by intrinsic motivational factors for SME growth.

\section{Correlation test}

The bivariate Pearson correlation analyses were also conducted to test any significant relationship between study variables.

The relationship in Table 7 for determining the variables of self-motivated business owners who exert an effort based on business growth interest was analysed:

- The self-motivation of business owners has a directly proportional correlation with the four variables relating to them exerting effort based on their interest for business growth. They include the SME owners who find solutions to business problems because they want to achieve business growth, the SME owners who are driven by a belief to produce the desired outcomes of their businesses, the need for advancement that has great impact on business growth and the SME growth aspirations that enable business owners to take risk in order to grow their businesses. They have coefficient $r$-values of $0.467,0.338,0.319$ and 0.394 , respectively (at $p>0.05$ ). This analysis indicates that self-motivated SME owners exert efforts based on their business growth interest.

- The variable relating to self-motivated business owners who exert effort based on their interest for business growth does not have a significant relationship with the variable of SME owners who take responsibility to grow their businesses for recognition purposes (at $p<0.05$ ). This analysis indicates that the growth of SME businesses does not depend on business owner recognition.

\section{Discussion}

This article investigated the influence of self-motivation and intrinsic motivational factors of business owners for SME growth. One hundred and twelve SME owners of furniture manufacturing businesses operating in the eThekwini Metropolitan Area in KwaZulu-Natal participated in the study. The findings indicate that if SME owners are intrinsically motivated, they exert effort based on business growth interests. They find solutions to business problems because they want to achieve growth. This gives an indication that the level of SME owners' motivation is crucial for SME growth in SA. In addition, it reveals that SME owners are self-motivated in growing their businesses. This is in line with the assertion of Abor and Quartey (2010) that SME growth is closely associated with overall business success and survival. The need to achieve success is the motive to do well and achieve a goal to a set of standards (Royle 2013). Thus, when SME owners are intrinsically motivated, their desires to learn, explore their interests, and engage their curiosity lead to the focus of novel ideas that help them grow their businesses even bigger.

Furthermore, the intrinsic motivation is an important enabler of creativity. It enhances self-motivation for business growth. Hence, the creative potential of SMEs will eventually lead to 
a better support of national goals for SA. They will thus be the enablers of economic growth for the country. The effort to stimulate creativity by broadening the range of cognitive information available, expanding the scope of attention towards assimilating a wider set of ideas and encouraging cognitive flexibility for identifying patterns and associations between ideas, will influence business growth (Barringer \& Ireland 2010). Intrinsic motivation enhances psychological engagement and builds energy for sustained effort (Grant \& Berry 2011). This increases the amount of time that SME owners are willing to work for business growth.

In addition, the results obtained during the study imply that the intrinsic motivational factors that stimulate the creativity process of the SME owners play a role in SME growth. The following conclusions relating to intrinsic motivational factors can be made:

- Self-motivated business owners have the ability to grow their businesses.

- An interest in leaning enhances SME owners' willingness to take risk.

- SMEs find new solutions to business problems because they want to achieve business goals.

- The need for advancement is the personal attribute that has greater impact on business growth.

\section{Limitations of the study}

The study was conducted in the eThekwini Metropolitan Area. Only SMEs in the furniture manufacturing sector participated. However, the respondents were geographically dispersed within the Metropolitan Area.

\section{Conclusion}

This article examined the influence of intrinsic motivational factors on business growth. It was established that the relationship between self-motivation and business growth is quite complex. This is consistent with the theory of planned behaviour, the importance of access to resources, as well as the access to opportunities for business growth. In addition, the intrinsic motivational factors that stimulate the creative process sustain business growth of SMEs. This helps the business to survive and grow in the early years of establishment.

\section{Acknowledgements Competing interests}

The authors declare that they have no financial or personal relationships that may have inappropriately influenced them in writing this article.

\section{Authors' contributions}

T.R.N. administered the questionnaire and provided a draft literature review while R.W.D.Z. analysed the raw data, aligned and consolidated the article into a final manuscript.

\section{References}

Abor, J. \& Quartey, P., 2010, 'Issues in SME development in Ghana and South Africa', International Research Journal of Finance and Economics 39, 215-228.

Antonites, A. \& Van Vuuren, J., 2014, 'Inducing entrepreneurial creativity, innovation and opportunity-finding skills', South African Journal of Economic and Management Sciences 8, 255-271. https://doi.org/10.4102/sajems.v8i3.1197

Arasti, Z., Zandi, F. \& Talebi, K., 2012, 'Exploring the effect of individual factors on business failure in Iranian new established small businesses', International Business Research 5(2), 2-11. https://doi.org/10.5539/ibr.v5n4p2

Bande, B., Fernàndez-ferrín, P., Varela-neira, C. \& Otero-neira, C., 2016, 'Exploring the relationship among servant leadership, intrinsic motivation and performance in an industrial sales setting', Journal of Business \& Industrial Marketing 31, 219231. https://doi.org/10.1108/JBIM-03-2014-0046

Baruch, Y. \& Holtom, B.C., 2008, 'Survey response rate levels and trends in organizational research', Human Relations 61(8), 1139-1160. https://doi. org $/ 10.1177 / 0018726708094863$

Becchetti, L., Castriota, S. \& Tortia, E.C., 2013, 'Productivity, wages and intrinsic motivations', Small Business Economics 41, 379-399. https://doi.org/10.1007/ s11187-012-9431-2

Coon, D. \& Mitter, J.O., 2010, Introduction to psychology: Gateways to mind and behavior. Study Guide, Wadsworth Cengage Learning, Boston, MA.

Csikszentmihalyi, M. \& Wong, M.M.H., 2014, 'Motivation and academic achievement: The effects of personality traits and the quality of experience', in Applications of Flow in Human Development and Education, pp. 437-466, Springer, Claremont, CA.

Deci, E.L. \& Ryan, R.M., 2011, 'Self-determination theory', Handbook of Theories of Social Psychology 1, 416-433.

Dawson, C., 2009, Introduction to research methods: A practical guide for anyone undertaking a research project, 4th edn., How To Books, Oxford.

Department of Trade and Industry, 2014, An annual review of small business in South Africa, viewed from http://www.budgetspeechcompetition.co.za

Gary-Perret, D. \& Mainali, A., 2012, 'Entrepreneurs driven by a need for self-fulfilment. An exploration of the origin of such a need and how entrepreneurs work towards fulfiling it', Journal of Business Administration 1(1), 69-113.

Grant, A.M. \& Berry, J.W., 2011, 'The necessity of others is the mother of invention: Intrinsic and prosocial motivations, perspective taking, and creativity', Academy of Management Journal 54, 73-96. https://doi.org/10.5465/AMJ.2011.59215085

Hennessey, B.A., 2010, 'The creativity-motivation connection', in J.C. Kaufman \& R.J. Sternberg (eds.), The Cambridge Handbook of Creativity, pp. 342-365, Cambridge University Press, Cambridge. https://doi.org/10.1017/CBO9780511763205.022

McClelland, D.C. \& Koestner, R., 1992, The achievement motive: Motivation and personality, Cambridge University Press, New York.

Mahembe, E., 2011, Literature review on small and medium enterprises' access to credit and support in South Africa, Underhill Corporate Solutions, National Credit Regulator (NCR), Pretoria, South Africa.

Nieman, G. \& Nieuwenhuizen, C., 2014, Entrepreneurship a South African perspective A model for entrepreneurial development, 3rd edn., Van Schaik Publishers, Pretoria.

Olawale, F. \& Garwe, D., 2010, 'Obstacles to the growth of new SMEs in South Africa: A principal component analysis approach', African Journal of Business Management 4, 729-738.

Pinder, C.C., 2014, Work motivation in organizational behavior, Psychology Press, London.

Ramukumba, T., 2014, 'Overcoming SME challenges through critical success factors: A case of SMEs in the Western Cape Province, South Africa', Economic and Business Review for Central and South - Eastern Europe 16, 19-38.

Robbins, S.P., Odendaal, A. \& Roodt, G., 2011, Organisational behaviour: Global and Southern African perspectives, Pearson, Cape Town.

Royle, M.T., 2013, 'Embeddedness: The nexus of learned needs, conscientious, and informal accountability for others', International Journal of Management and Marketing Research 6(1), 1-41.

Royle, M.T. \& Fox, G., 2011, 'The relationship between psychological strain, selfregulation, and informal accountability for others', International Journal of Management and Marketing Research 4, 1-18.

Royle, M.T. \& Hall, A.T., 2012, 'The relationship between McClelland's theory of needs, feeling individually accountable, and informal accountability for others', International Journal of Management and Marketing Research 5, 21-42.

Shepherd, D. \& Wiklund, J., 2009, 'Are we comparing apples with apples or apples with oranges? Appropriateness of knowledge accumulation across growth studies', Entrepreneurship Theory and Practice 33(1), 105-123.

Snyman, H.A., Kennon, D., Schutte, C.S.L. \& Leipzig, K.V., 2014, 'A strategic framework to utilise venture capital funding to develop manufacturing SMEs in South Africa', South African Journal of Industrial Engineering 25, 161. https://doi.org/10.7166/ 25-2-816

Tu, Y. \& Lu, X., 2014, 'Do ethical leaders give followers the confidence to go the extra mile? The moderating role of intrinsic motivation', Journal of Business Ethics 135, 129. https://doi.org/10.1007/s10551-014-2463-6

Wiklund, J., Patzelt, H. \& Shepherd, D.A., 2009, 'Building an integrative model of smal business growth', Journal of Small Business Economics 32(4), 351-374. https:// doi.org/10.1007/s11187-007-9084-8

Zimmerman, M.A. \& Chu, H.M., 2013, 'Motivation, success, and problems of entrepreneurs in Venezuela', Journal of Management Policy and Practice 14, 76. 